\title{
Some Diversification Factors of Old Industrial Regions' Economy and Transition to the Innovative Development
}

\author{
Olga Tabashnikova ${ }^{1}$ \\ ${ }^{1}$ Plekhanov Russian University of Economics, Kemerovo Institute (branch), 650992 Kemerovo, \\ Kuznetskiy Av. 39, Russia
}

\begin{abstract}
The article presents the grounds for the necessity to diversify the mono-economy of old industrial regions and its transition to the innovative development based on the interaction of small and large businesses with the support of municipal, regional and governmental authorities. The examples of the world practice in state regulation of depressed territories of old industrial type and the participation of multinational corporations in their modernization are given. The role of business groups in the diversification of the Kemerovo region economy is described, as well as the importance of supporting this process by the governmental authorities.
\end{abstract}

\section{Introduction}

The need to diversify the mono-profile (mono-product, mono-industrial) economy of old industrial regions, including the Kemerovo Region, is due to the objective requirement of their sustainable development and increase of social and economic parameters of the territorial management system. One of the important factors of this process is the effective interaction of small and large business. However, in modern economy, when the existing economic, production, and other links and mechanisms lose their importance and new ones are just being established, to create such interaction and ensure its development the purposeful efforts of the authorities on federal, regional and municipal levels are necessary.

\section{Materials and Methods}

It should be noted that there is no "exact" (single, universal) definition of the term "old industrial region", despite the fact that many scientists have paid attention to this phenomenon during the past twenty five years in Russia [1-5]. The fact is that the definitions proposed by the researchers are determined by the aims of this or that study. At the same time, a sufficiently extensive scientific material accumulated in this sphere of research allows us making some generalizations.

The English scientist R. Hudson believes that the old industrial regions, which he calls "the world's workshops," lose their importance over time [1]. In the development of the 
strategy for the survival of "peripheral areas," to which mining areas exactly belong, according to Hudson, four possible reorganization options should be considered:

1. The development of small and medium-sized enterprises, the search for ways to create new jobs in small business, the development of the so-called entrepreneurial "culture of self-employment" instead of large-scale production.

2. The creation of an updated economic system based on the branches of large, and, if possible, multinational companies attracted to the region, upon condition of propaganda of an attractive image of the territories.

3. Transition to the economy of "service" - tourism, recreation, entertainment, etc.

4. The refusal from the production sphere and the transformation of territory into a zone of "housing and consumption", where the main source of living is state benefits and subsidies.

However, R. Hudson emphasizes, that only local initiatives in implementing any variant or combination of options are not enough to solve the problems of territory restructuring $[1]$.

At the same time, D. Sadler, being a member of the Cabinet of Ministers of Great Britain, drew attention to the fact that the depressive state of some territories leads to the rejection of entire regional population groups from the processes of social and economic development of society. By the example of some old industrial territories of Western Europe one can observe that low labor status, the regressive distribution of incomes, the underdevelopment of social infrastructure; the contradictions of social strata escalate the social and political situation in such areas [2].

\section{Results and Discussion}

At present in Western Europe there is a certain system of state regulation of depressed territories of the old industrial type. Common principles for all countries of this system are the following [6-8]:

- recognition of the government support as a necessary condition for the recovery of crisis and depressed regions, which should be provided in advance, before the crisis, at the stage of stable development;

- implementing regional policy to have an impact not on the region as a whole, but on the most problematic part of it;

- solving priority social problems by creating new highly skilled jobs for local personnel, developing social infrastructure, preventing the decline in income of the population;

- stabilization of peripheral old industrial areas through the development in them new high-tech industries, business services, recreation;

- orientation to the internal resources of the regions to achieve the stability of their development.

As a rule, the old industrial areas play a special role in the development of economy of the territories, but they have a whole range of problems, from ecological to demographic ones. The main problem of such regions, and this fully applies to the Kemerovo region, is the excess of production capacity, represented by large and medium-sized enterprises with obsolete equipment and technologies.

A basic feature of the Kemerovo region as an old industrial zone is its predominantly resource nature. Herewith the main economy resource in the absolute majority of Kuzbass towns, and in fact the source of their existence, is coal deposits the volume of which is limited, and, according to experts, will provide the operation of coal mines and open pits for the next 50-60 years.

By the level of economic development the Kemerovo region occupies an intermediate place between the relatively developed and moderately developed regions of Siberia. 
However, the following trend attracts attention: during recent years the sectoral structure of the gross regional product (GRP) of the Kemerovo region has become more primary. According to the Independent Institute of Social Policy, the share of extractive industry increased from $20.6 \%$ to $28.4 \%$ from 2004 to 2008 , while the share of manufacturing industry fell from $24.5 \%$ to $19.8 \%$. The reduced life expectancy and educational level of the population do not allow the Kemerovo region rising above the 31 st place by the HDI in the ranking of regions (2008). Earlier the position of the region was even worse (35-42 places in 2004-2007). The region's quality of life index grew in 2002-2005; it increased from the 26th to the 11th place. As for the innovation index Kemerovo region occupies the 30th place. The innovative development of the region is hampered by a small proportion of those employed in science and scientific development. In 2000-2004, by the index of democracy, the region occupied only the 66th place. Thus, according to the integral social indices, in 2008 the Kemerovo Region lagged behind most of the developed industrial regions of the country.

At the same time, the recovery of enterprises of the Kemerovo region also began earlier than in other Russian regions. This was due to the improvement of the metallurgy global market. However, this impetus for growth has dried up in 2010. The decline in 2009 as a whole was slightly less than the total for Russia ( 9 and $11 \%$, respectively). The production of the most important type of products - steel - decreased by $7 \%$ and amounted to 7.6 million tons (13\% of all-Russian production).

Unfortunately, in 2016 the value of integral indicator of the development of the Kemerovo region fell even further and amounted to 0.152 , as a result of which the region took the 78th place out of the 80th. The economic, social and environmental indices were 0.53 ; 0.223 and 0.03 , respectively.

The volume of production of coal mining industry in 2008 was 178 million tons. Crisis helped to increase the concentration of Russian coal production in Kuzbass: if in 2008 it accounted for $55 \%$ of Russian coal production, in 2009 it was $59 \%$. At the same time, the volume of coal mining in Kuzbass is constantly increasing. Thus, the volume of coal production in 2016 increased by $5.4 \%$ compared to the level of 2015 and amounted to 227.4 million tons.

The coal mining industry is the main branch of Kuzbass specialization. The most important centers of coal industry are Prokopyevsk, Mezhdurechensk, Belovo, Kemerovo, Novokuznetsk, Osinniki, among the districts are Leninsk-Kuznetsk, Belovsky, Kemerovo, Novokuznetsk and Prokopyevsky.

Leading coal mining companies are owned by large Russian business, mainly metallurgical. Russian metallurgical companies bought mines and pits that extracted coking coal in order to control the entire technological chain of steel and rolled steel production. OJSC "United Coal Company "Yuzhkuzbassugol" and the mine "Raspadskaya"are controlled by the holding company Evraz Group. Kuzbassugol (currently OJSC Coal Company "Severny Kuzbass") is owned by OJSC "Severstal", OJSC Coal Company "Yuzhniy Kuzbass" - by metallurgical company OJSC "Mechel".

The largest company in the Kemerovo Region, OJSC Coal Company "Kuzbassrazrezugol", which accounts for a quarter of Kuzbass coal produced in 2009, is a part of the OJSC "Urals Mining and Metallurgical Company". Moreover, this property is not linked by a single technological chain, since the "Ural Mining and Metallurgical Company" is the second largest copper producer in Russia.

In the 90 s of the 20th century, coking coals were supplied primarily to the domestic market. Their consumers were mainly metallurgical plants. At that time, the producers of power generating coals were export oriented. However, in the second half of the 2000s the export vector of Kuzbass grew stronger due to the increase in world prices for coal. In 2006 , the volume of export of Kuzbass coal exceeded the volume of supplies to the domes- 
tic market for the first time, and in 2016 the shipment of products exceeded 188.9 million tons for the year - an increase of 7.8 million tons, 66\% was exported. In 2016, Kuzbass significantly expanded the sales geography by supplying coal to Bosnia and Herzegovina, Chile. At present Kuzbass supplies coal to 55 countries of the world [6].

The enterprises of metallurgical industry provide more than half (almost 60\%) of the production of the processing industry in the Kemerovo region. Two full-cycle metallurgical plants are located in Novokuznetsk and since 1999 belong to the holding company EVRAZ Group. One of them, OJSC "Zapadno-Sibirskiy metallurgicheskiy kombinat", is one of the five largest in Russia and in the thirty of the world's largest steel works. Its capacity is 8 million tons of steel and 5 million tons of rolled steel a year. Novokuznetsk Metallurgical Complex (NMC), built during the industrialization period, has less capacity and specializes in the production of rails (about 70\% of Russian production). From July 1, 2011, OJSC "EVRAZ Zapadno-Sibirskiy metallurgicheskiy kombinat" merged ZSMK and NMC. In 2016 EVRAZ ZSMK produced 5.4 million tons of cast iron, 6.9 million tons of steel, 6.3 million tons of steel products. Except the enterprises of ferrous metallurgy Novokuznetsk aluminum plant is located in the city. It belongs to the company "Russian Aluminum" and is the fifth largest aluminum producer in Russia.

Among the enterprises of manufacturing industry of the Kemerovo region there are such enterprises as the OJSC "Yurga Machine-Building Plant" (Yurga), the largest machinebuilding enterprise in the region producing mining equipment, the Kuzbass Railcar Company (Kemerovo), a branch of "Altayvagonzavod" that manufactures cargo platforms and components for wagons, OJSC Holding Company "Sibirskiy Cement" (the headquartered is in Kemerovo, the main enterprise "Topkinsky Cement" is in Topki), which produces cement for housing and road construction, OJSC "Azot" - a powerful industrial complex, which produces more than 40 kinds of chemical products on the basis of modern chemical equipment, etc. All of these companies have financial difficulties in recent years.

At the same time, the experts note that for the Kemerovo region the general tendency of increasing the service sector in economy is not typical: it makes just over $40 \%$ of GRP, while in Russia as a whole it is $56 \%$. Among the main threats to the development of the region it is necessary to single out the following:

- mono-branch structure of the economy of the Kemerovo region;

- the dependence of regional budget and, accordingly, municipal budgets on large taxpayers;

- manufacturing of products with low added value;

- the dependence of economy on the market prices for coal and ferrous metals;

- the dependence of economy on transport and energy tariffs;

- high degree of fixed assets depreciation;

- insufficient level of use of modern management and labor management systems;

- infrastructure constraints;

- the lack of skilled labor force;

- the shortage of investment resources.

At the same time, for municipal entities of the Kemerovo region, which have a singlesector economic structure dominated, as a rule, by one type of economic activity, there are a number of factors that determine the opportunities for diversification of economy and transition to the innovative development. Among them are:

1) dominance of the fuel and energy complex as a source of financial resources for the future transformations;

2) the availability of relatively high-tech industrial and human resources, historically formed since the times of the USSR; 
In our opinion the most interesting example of industry diversification on such old industrial area as the Kemerovo Region is the experience of regulating the problems in the Ruhr Area in Germany.

The old industrial Ruhr Area, which played a huge role in Germany's industrialization, unites today in one communal union (the Ruhr region) 11 cities and adjacent areas occupying an area of 4,4 thousand square $\mathrm{km}$ with a population of 5.4 million people.

After the Second World War, the region restored its economic power within a decade, based on the coal industry. 50 new mines were built, and coal production reached 112.8 million tons in 1954. However, already in the second half of the 1950s, a crisis started in the Ruhr coal industry due to the imported oil competition. Coal production fell sharply, many mines were closed, the crisis spread to the coal-related industries, and unemployment increased.

The government of the Federal Republic of Germany chose the way of special economic support for the Ruhr Area. Subsidies were granted to the coal industry, the coal consumption, especially to the Central Heating and Power plants, in order to maintain the consumer demand for coal. In 1968, a federal law was adopted to restructure and recover the coal industry and the coal-mining region, according to which the government determined the minimum required volume of coal production in the country, the amount of subsidies, subsidies to the freed-up workers and their retraining costs.

In 1969, the whole Ruhr coal industry was merged into one concern "Rourkole" ("Ruhr Coal") on the basis of the agreement of the German Minister of Economy, the government of North Rhine-Westphalia, the owners of mines and trade unions.

Coal mining enterprises were bound by the long-term contracts with metallurgical plants and power plants. A specific tax - "coal pfennig" - had a significant impact on the stabilization of coal sales. Each extra pfennig (0,01 marks) paid by the consumers extra price of kilowatt-hour of electricity came to a special fund for coal consumption, all of which went to buy German coal instead of cheaper foreign one. The tax was abolished in 1995.

These measures of the government of the Federal Republic of Germany allowed avoiding the collapse of coal production and gaining time for the gradual and controlled restructuring of the entire Ruhr economy.

The main directions of restructuring the region's economy were:

- the modernization of "old" industries;

- the development of higher education;

- the creation of technology centers and, on their basis, high-tech industries;

- improving the environment.

Industrial modernization covered most of the metallurgical and chemical plants, heavy engineering enterprises. Ecologically polluted industries were eliminated, the range of products was radically updated, and industrial territories were reduced. In 1960-1980 in the Ruhr region 5 new universities were founded with the aim of creating training centers, reducing youth unemployment, limiting emigration from the region and attracting new personnel. A significant part of local students studies free of charge, low-income students receive scholarships.

In 1993, the total number of students reached 150 thousand, which was twice the number of mines, the number of scientists and teachers increased multifold. Twelve technological centers were created that contributed to strengthening the scientific and innovative potential of the region, providing premises for entrepreneurs, equipment, logistics, organizational and financial assistance.

Elimination and recycling industrial waste, protection and expansion of the green landscape were coordinated by the "Municipal Union" using various financial sources. The result of this program was the ecological improvement of the entire region, and the most pol- 
luted area along the Emscher River was turned into a huge landscape park with a length of $320 \mathrm{~km}$, containing recreation areas and eco-zones, technology museums and innovative exhibitions [6].

The effect of specialization may arise when using highly specific material and / or intangible assets, for example, the interaction of a large construction company "Kemerovopromstroy" with a small enterprise "Finestra", which supplies it with $90 \%$ of the production (wood constructions for building) on the basis of long-term contracts. There are a lot of examples of this kind in economic activity, in particular, the transfer to the audit firm a part of the financial planning functions by a large enterprise "Kemerovohimmash". Aaccounting, providing legal support, consulting, recruiting, advertising and other services provided by firms specializing in their implementation to a wide range of small and large enterprises. The need to distinguish specialization as the basis for interaction between small and large businesses is determined by the processes of division of labor, and also by the fact that it is small business that largely determines the viability and effectiveness of new types of business taking innovative risks.

Complementary (additional) effect occurs when using tangible assets (tools, raw materials, materials) and is focused on their full use. An example of a more complete use of production capacity is the provision by the large enterprise "Kemerovo plant of reinforced concrete structures" of existing equipment, which is engaged in the basic production of an average 1.6 shifts, to a small enterprise that produces paving slabs. An example of more complete use of raw materials is the production of household products by a small enterprise "Kuzbasski Scarabei" from the residues left as a result of production at a large chemical enterprise "TOKEM".

\section{Conclusion}

We emphasize that the desire to achieve such effects in an explicit or implicit form acts as one of the incentives for the interaction of different forms of business. The basis for solving practical problems of territorial-industrial integration development is the theory of clusters. According to it, the production structure of the region should be developed in such direction that allows using the product of one industry for the needs of the others.

Thus, between all the industries represented in the region stable links are being created. It allows supporting these industries and promoting the innovative development of the economy of old industrial region.

\section{References}

1. R. Hadson, Economia Restraction Tendencies and their Implications for Development Strategies in the Peripheries of Europe (Birmingham, Lommond, 1994)

2. D. Sadler, Marginality in the New Europe (Birmingham, Lommond, 1994)

3. H. Burke, E. Hough, D.J.R. Morgan, L. Hughes, D.J Lawrence, UK Land Use Policy, , 47: 321-331 (2015)

4. M. Cała, A. Ostręga, Arch. Min. Sci., 58:2, 361-374 (2013)

5. J. Kretschmann, Euras. Min. 2, 52-56, (2015)

6. J. Kretschmann, Int. J. Min. Sci. Tech. 23, 659-663 (2013)

7. A. Prossek, H. Schneider, H.A. Wessel, B. Wetterau, D. Wiktorin, Atlas der Metropole Ruhr-Vielfalt und Wandel des Ruhrgebietes im Kartenbild, Emons Verlag (Hamburg, Hollmann, 2011) 
8. Gespräch mit Experten des Regionalverbandes Ruhr in Essen am 04.12.2012: Michael Schwarze-Rodrian (Netzwerke Ruhr, RVR, 2013) 
